\title{
SCREENING FOR ANTIMICROBIAL ACTIVITY OF NATURAL PRODUCTS USING A MICROPLATE PHOTOMETER
}

\author{
Karina F. Devienne ${ }^{1}$; Maria Stella G. Raddi* \\ ${ }^{1}$ Instituto de Química de Araraquara, Universidade Estadual Paulista, UNESP, Araraquara, SP, Brasil. ${ }^{2}$ Faculdade de Ciências \\ Farmacêuticas de Araraquara, Universidade Estadual Paulista - UNESP, Araraquara, SP, Brasil
}

Submitted: August 13, 2001; Returned to authors for corrections: November 22, 2001; Approved: May 05, 2002

\section{SHORT COMMUNICATION}

\begin{abstract}
The microdilution technique, using a microplate photometer, to determine the minimal inhibitory concentration (MIC) for a natural product was compared to the serial tube dilution method. The MIC obtained for Paepalantine against $S$. aureus was the same by the two methods, showing an antimicrobial effect similar to chloramphenicol.
\end{abstract}

Key words: Antimicrobial activity, microdilution, spectrophotometric method

Due to the development of resistant bacterial strains, the number of publications on antibacterial activity of phytochemicals is increasing. The two most commonly used methods for screening of potential antibacterial plant compounds are the disc diffusion test and the dilution plate assay. These techniques do not distinguish bactericidal and bacteriostact effects and the minimal inhibitoty concentration (MIC) can not be determined (1). In the screening of antimicrobial compounds, the microplate method has provided a potentially useful technique for determining MICs of large numbers of test samples, requiring small amounts of substances; this can be particularly important if the antimicrobial is scarce as is the case for many natural products (3). This method can also be used for a wide variety of microorganisms, is not expensive and presents reproducible results. The purpose of this study was to evaluate the microplate method for screening for antimicrobial activity of extracts and natural products.

The MICs for ampicilin, chloramphenicol and the isocoumarin 9,10-dihydroxy-5,7-dimethoxy-1H-naphtho (2,3c)pyran-1-one (Paepalantine) (6) were evaluated using a spectrophotometric microdilution method (SMM) by comparison with the macrodilution method (MM) against Staphylococcus aureus (ATCC 25923) and Escherichia coli (ATCC 25922).
Ampicillin (Emelffar Comercial, Brazil) and chloramphenicol (Searle, USA) were prepared as stock solutions of $5.12 \mathrm{mg} / \mathrm{ml}$ in nutrient broth (NB) containing $(\mathrm{g} / \mathrm{l})$ glucose 1.0, yeast extract 2.5 and tryptone 5.0. The isocoumarin (stock solution at 12.5 $\mathrm{mg} / \mathrm{ml}$ in DMSO) was diluted to $2 \mathrm{mg} / \mathrm{ml}$ in the same broth. Subsequently, the solutions were diluted in NB. The wells of a 96-well ELISA tray were filled with $100 \mu 1$ of exponentially growing culture (about $10^{8}$ colony-forming units $/ \mathrm{ml}$ ) and added with $100 \mu \mathrm{l}$ of diluted drug. The absorbance of each will was determined using an automatic ELISA tray reader adjusted at $620 \mathrm{~nm}$ (Spectra \& Rainbow Readers, Tecan). The plate was incubated at $37^{\circ} \mathrm{C}$ for $18 \mathrm{~h}$, agitated and the absorbance was read again in the reader at the same wavelength. These absorbance values were subtracted from those obtained before incubation. This procedure eliminated the interference of the tested substance. All tests were performed in triplicate. The MICs value for a drug was expressed as the lowest concentration that inhibits the bacterial growth. The macrodilution method was performed according to Jorgensen et al. (4).

The MIC determined by the spectrophotometric method was defined as the concentration at which there was a sharp decline in the absorbance value. MICs obtained with spectrophotometric

\footnotetext{
* Corresponding author. Mailing address: Faculdade de Ciências Farmacêuticas de Araraquara, UNESP, Caixa Postal 502. $14801-970$ - Araraquara, SP, Brasil. Phone: (+5516) 201-6559, Fax: (+5516) 232-0880. E-mail: raddims@fcfar.unesp.br
} 
microdilution and macrodilution methods for the antibiotics and Paepalantine against $S$. aureus and E. coli are shown in Table 1 and Fig. 1.


Figure 1. Effect of ampicillin (A), chloramphenicol (B) and Paepalantine (C) against E. coli ( $-\mathbf{-})$ and S. aureus ( $(\mathbf{-}-)$ by spectrophotometric method.
Table 1. Comparison of MIC values for ampicilin, chloramphenicol and Paepalantine by macrodilution method (MM) spectrophotometric microdilution method (SMM).

\begin{tabular}{lcccc}
\hline & \multicolumn{4}{c}{$\begin{array}{c}\text { Minimal Inhibitory Concentration } \\
(\mu \mathrm{g} / \mathrm{ml})\end{array}$} \\
\cline { 2 - 5 } & \multicolumn{2}{c}{ S. aureus } & \multicolumn{2}{c}{ E. coli } \\
\hline Compounds & MM & SMM & MM & SM \\
Ampicillin & 0.125 & 0.125 & 16 & 8 \\
Chloramphenicol & 16 & 16 & 8 & 8 \\
Paepalantine & 15.63 & 15.63 & $>500$ & $>500$ \\
\hline
\end{tabular}

For chloramphenicol, the MIC visual determination obtained by $\mathrm{MM}$ and the endpoint of the optical density measurement using SMM presented good correlation. For ampicillin, the MICs obtained by the two methods were the same for $S$. aureus but there was a small discrepancy (1 dilution step) for $E$. coli. This may have resulted from error in the visual readings because gradual changes in density of growth make the visual endpoint difficult to determine. This fact is in agreement with results reported by Turner et al. (5) who found that the visual endpoints for ampicillin against gram-negative rods were more difficult to detect than for others antibiotics. The MIC to Paepalantine for S. aureus was the same by both methods showing an antibiotic effect similar to chloramphenicol. This compound at $500 \mu \mathrm{g} / \mathrm{ml}$ was ineffective against $E$. coli.

The methods used to study the antimicrobial potential of plant compounds are diverse, making the comparison of the obtained MICs very difficult. Standardized in vitro tests are needed for screening trials, thus more studies should be conducted for MIC determination of natural products in order to get results that are comparable to those of currently used antibiotics (2).

\section{ACKNOWLEDGMENTS}

We thank the Fundação de Amparo à Pesquisa do Estado de São Paulo (FAPESP) for a grant to K.F.D. and PADC-FCFUNESP for funding M.S.G.R.

\section{RESUMO}

\section{Triagem da atividade antimicrobiana de produtos naturais utilizando leitor de microplacas}

A técnica de microdiluição para a determinação da concentração inibitória mínima (CIM) de um produto natural utilizando espectrofotômetro para microplacas foi comparada ao método de diluição seriada em tubo. A CIM da Paepalantina para $S$. aureus foi a mesma por ambos métodos demonstrando possuir efeito antimicrobiano semelhante ao cloranfenicol.

Palavras-chave: Atividade antimicrobiana, microdiluição, método espectrofotométrico. 


\section{REFERENCES}

1. Chand, S.; Lusunzi, I.; Veal, D.A.; Williams, L.R.; Karuso, P. Rapid screening of the antimicrobial activity of extracts and natural products. J. Antibiotics, 47: 1295-1304, 1994.

2. Cowan, M.M. Plant products as antimicrobial agents. Clin Microbiol Rev., 12: 564-582, 1999.

3. Ellof, J.N. A sensitive and quick microplate method to determine the minimal inhibitory concentration of plant extracts for bacteria. Planta Medica, 64: 711-713, 1998.
4. Jorgensen, J.H.; Turnidge, J.D.; Washington, J.A. Antimicrobial susceptibility tests. In: Murray, P.R.; Baron, E.J.; Pfaller, M.A.; Tenover, F.C.; Yolken, R.H. (eds.). Dilution and disk diffusion methods. ASM Press, Washington DC, 1999, p.1526-1543.

5. Turner, A.; Hawkey, P.M.; Pedler, S.J. Computer-assisted determination of antibiotic susceptibility in photometer-read microtiter plates. J. Clin. Microbiol., 18: 996-998, 1983.

6. Vilegas, W.; Roque, N.F.; Salatino. A.; Giesbrecht, A.M.; Davino, S. Isocoumarin from Paepalanthus bromelioides. Phytochemistry, 29: 2299-301, 1990 